\title{
Understanding dengue transmission by using participatory research and community-focused strategies for prevention and control in Bangladesh
}

\author{
Parnali Dhar Chowdhury*, Emdad Haque \\ From First International Science Symposium on HIV and Infectious Diseases (HIV SCIENCE 2012) \\ Chennai, India. 20-22 January 2012
}

\section{Background}

Globally, dengue has become one of the most alarming infectious diseases and its resurgence reflects the failure of traditional reductionistic disciplinary approach. Because neither an effective vaccine nor an effective vector control program is available for dengue prevention and control, a Community-Based Approach (CBA) to vector control and individual behavior change has been implemented in many countries. However, by and large, the CBA has failed as it ignored local community members' basic needs and perspectives in these processes. By challenging reductionist notions, this research will delineate the mental maps of local urban residents of the City of Dhaka, Bangladesh concerning dengue transmission and methods of dengue prevention and control.

\section{Methods}

This study involved focus group discussion in 3 wards of Dhaka City Corporation, semi-structured interview of 30 stakeholders representatives; 900 ward/community members (300 from each ward); 18 policy- and/or decision makers (national and local institutions) and community members' mental map construction of 24 ward representatives (supplemented by 300 ward members).

\section{Results}

This study revealed the lack of intersectoral coordination between local and national institutions dealing with disease and household sanitation, and highlights the difficulties in avoiding dengue vectors in urban areas with

* Correspondence: umdharch@cc.umanitoba.ca

Natural Resources Institute, University of Manitoba, Winnipeg, Canada irregular water supply, poor sanitation services, and finally the location of large and small construction zones all over the city.

\section{Conclusion}

The conclusion emphasizes the importance of the knowledge about the daily problems faced by the community members and partnership needed in all sectors to address water supply problem and disease surveillance systems.

Published: 4 May 2012

doi:10.1186/1471-2334-12-S1-P92

Cite this article as: Chowdhury and Haque: Understanding dengue transmission by using participatory research and community-focused strategies for prevention and control in Bangladesh. BMC Infectious Diseases 2012 12(Suppl 1):P92.

Submit your next manuscript to BioMed Central and take full advantage of:

- Convenient online submission

- Thorough peer review

- No space constraints or color figure charges

- Immediate publication on acceptance

- Inclusion in PubMed, CAS, Scopus and Google Scholar

- Research which is freely available for redistribution 